\title{
An analysis of medical records of patients diagnosed with cardiomyopathy and provided with inpatient palliative care
}

\begin{abstract}
Palliative care, currently also called 'supportive care', is a specialist care that focuses on improving the quality of life by relieving symptoms and stress in patients with an incurable disease. The actions taken are aimed at preventing suffering, treating pain and other somatic symptoms as well as at helping to solve psychosocial and spiritual problems, along with support for the patient's family.

Heart failure caused by cardiomyopathy is an incurable disease that limits vital functions and is provided with guaranteed palliative and hospice care. This is a progressive disease and therapy only slows down its course, which means that the patient will be accompanied by the diagnosis throughout their whole life and this disease will be the cause of death in some cases.

This article includes an analysis of the documentation of patients with cardiomyopathy, in whom standard methods of treatment, facilitating the improvement of heart function, proved to be ineffective. In order to improve the quality of life, patients were transferred to the Department of Palliative Medicine.
\end{abstract}

Palliat Med Pract 2020; 14, 1: 7-11

Key words: cardiomyopathy, treatment, heart failure, symptoms

\section{Introduction}

The majority of patients in Poland's palliative medicine units are cancer patients (83.4\%) [1], however, current epidemiological data indicate an increase in the demand for hospice care among patients suffering from non-cancer diseases, including advanced heart failure [2]. Heart failure is a common condition, particularly in an ageing population, and can be the result of various causes. One of the groups of diseases, which lead to the development of circulatory failure, are cardiomyopathies.

Cardiomyopathies can be divided into primary and secondary ones - caused by toxic effects of drugs, e.g. chemotherapeutics, but also as the result of metabolic, endocrine or autoimmune diseases [3]. Palliative care in patients with cardiomyopathy includes treat- ment of somatic symptoms (i.a. pain, dyspnoea, nausea, oedema) and regulation of mental stress [4]. The progressive nature of cardiomyopathy combined with high mortality makes palliative care an important part of the therapeutic approach [5]. Standard treatment does not always sufficiently reduce the patient's suffering and significantly improve their quality of life [6].

It should be emphasised that patients with cardiomyopathy, especially those in advanced stages of the disease, suffer from numerous comorbidities, often insufficiently diagnosed and treated. Drug interactions between the medicinal products applied are not uncommon. The scope of care should be coordinated with the primary treatment and include the treatment of symptoms related to the disease [7]. According to the Annex to the Regulation of the Minister of Health of 29 October

\section{Address for correspondence:}

Aleksandra Niemiec

Centre for Palliative Medicine in Hospice in Będkowo

e-mail: alex.niemiec@gmail.com

Palliative Medicine in Practice 2020; 14, 2, 7-11

Copyright (c) Via Medica, ISSN 2545-0425

DOI: $10.5603 /$ PMPI.2020.0003 
2013 on palliative care, guaranteed medical services may be provided to patients with cardiomyopathy [8].

\section{Patients and methods}

The medical records of 26 patients, diagnosed with cardiomyopathy and hospitalised at the Department of Palliative Medicine, were analysed. All analysed patients were admitted to the hospice from 26 May 2014 to 15 January 2020. Age, gender, type of cardiomyopathy as well as comorbidities, applied pharmacological and non-pharmacological treatment and the presence of implantable electronic devices were analysed. Due to non-interventional type of this study, Ethical Committee consent was waived.

\section{Results}

The group of 26 patients analysed comprised 17 men (65\%) and 9 women (35\%), the average age was 74 years. The oldest patient was 95 , the youngest - 36. The most numerous group were patients with unclassified cardiomyopathy - 13 persons; dilated cardiomyopathy was diagnosed in 11 patients and hypertrophic cardiomyopathy in 2 patients. Intensified symptoms of circulatory failure caused by the underlying disease were the reason for referral of all patients to the Department of Palliative Medicine. An analysis of comorbidities (Table 1) shows that patients with cardiomyopathy most frequently suffer from hypertension, diabetes mellitus, cardiac dysrhythmia, renal diseases and lipid metabolism disorders. The
Table 1. Comorbidities in patients in palliative care, diagnosed with cardiomyopathy

\begin{tabular}{llcc} 
& Comorbidities & Number & Prevalence (\%) \\
\hline 1. & Hypertension & 18 & 69 \\
\hline 2. & Diabetes & 9 & 35 \\
\hline 3. & Arrhythmias & 10 & 38 \\
\hline 4. & Myocardial infarction & 12 & 46 \\
\hline 5. & Stroke & 9 & 35 \\
\hline 6. & Renal diseases & 6 & 23 \\
\hline
\end{tabular}

history taking revealed that more than half of the patients were diagnosed with more than two of these disorders.

The patients were referred to the Department of Palliative Medicine from internal medicine wards of other hospitals. The average time of the patients' stay at the Department of Palliative Medicine was 79 days (the shortest time of hospitalisation - 1 day, the longest -497 days); 9 patients died, 15 were discharged from hospital, 4 patients were transferred to internal disease wards, and 11 patients were referred to Home Hospice or primary care facilities. Furthermore, on the last day of the analysis, 2 patients were still at the Department of Palliative Medicine.

Beta-blockers and antithrombotic or antiplatelet drugs, which were administered to 21 patients (81\%), were most frequently used during treatment (Fig. 1). Drugs affecting the central nervous system (anxiolytics, antipsychotics, hypnotic drugs, antide-

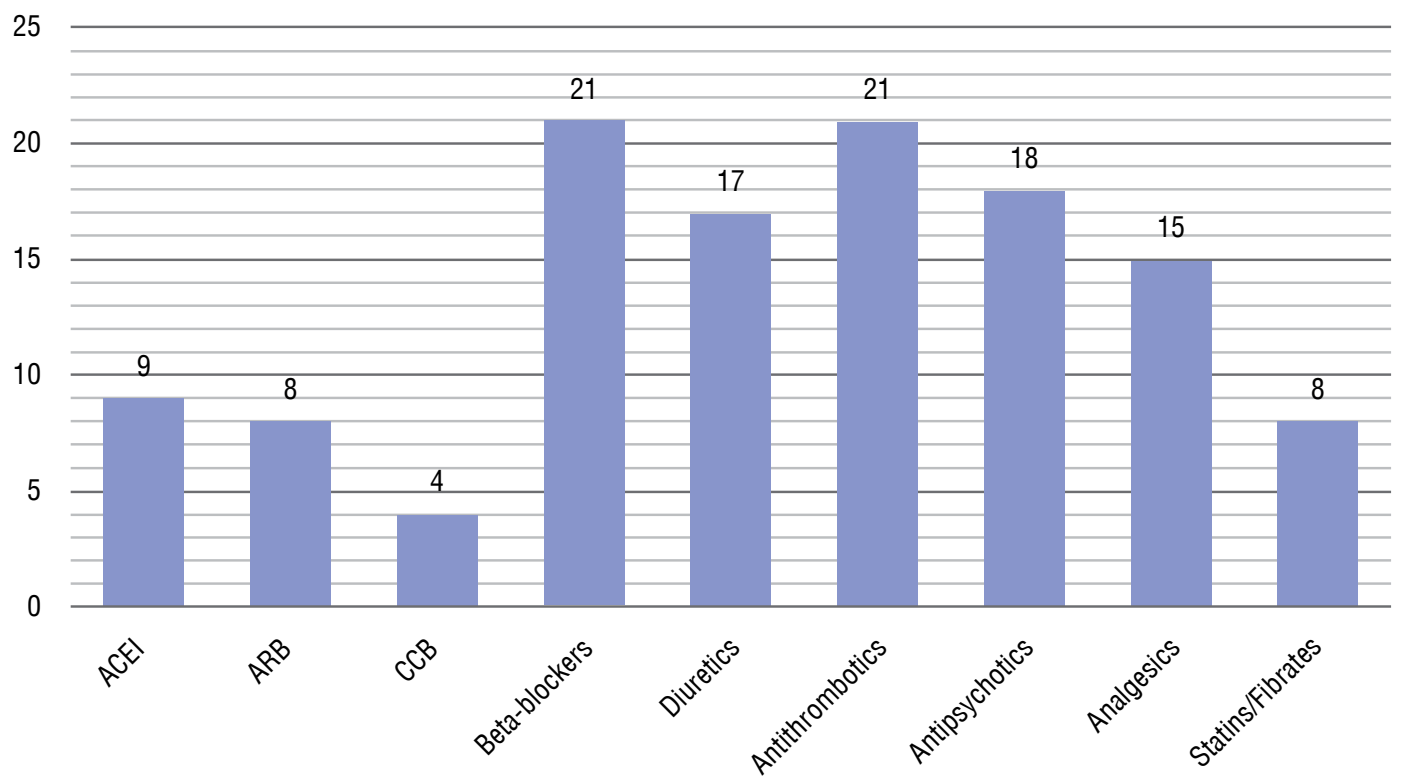

Figure 1. Medicines applied by patients in palliative care, diagnosed with cardiomyopathy: ACEI — angiotensin-converting-enzyme inhibitors; ARB — angiotensin II receptor antagonist; CCB — calcium channel blockers 
pressants) were applied in 18 patients (69\%), loop or thiazide diuretics were administered to 17 patients, opioid analgesics - to 15 patients. In addition to the above-mentioned pharmaceuticals, patients received antidiabetic drugs, ACE inhibitors, sartans and hypolipidemic drugs. The majority of patients underwent passive intranasal oxygen therapy or oxygen therapy with the use of a face mask. In all patients, diuresis was controlled, daily fluid intake was measured as well as abdominal circumference (once a day) to exclude overhydration. Furthermore, 5 patients had electronic devices implanted to support normal cardiac activity: 3 patients had VVI pacemaker, others - CRT-D or ICD resynchronisation system. All patients underwent careful, individually selected physiotherapy and received, along with their relatives, psychological support.

\section{Discussion}

Guaranteed medical services in palliative and hospice care may be provided to patients who have been diagnosed with the disease entities listed in the Regulation of the Minister of Health of 29 October 2013 [8]. The list of adult patients is limited - among cardiovascular diseases only cardiomyopathies are included. Not all cardiology and internal medicine specialists are informed about this fact; therefore, despite the indications, they do not refer patients to palliative care units. To provide patients suffering from cardiomyopathy with the best possible health care quality, the earliest possible cooperation of a cardiology specialist with a specialist in palliative medicine is of great importance.

Cardiomyopathies cause heart dysfunction and, consequently, heart failure, and their aetiology varies. In accordance with the WHO division, cardiomyopathies were classified as follows: dilated cardiomyopathy, hypertrophic cardiomyopathy, restrictive cardiomyopathy, arrhythmogenic right ventricular cardiomyopathy (ARVC) and unclassified cardiomyopathies. According to data from the Interna Szczeklika 2020 handbook, dilated cardiomyopathy is the most common type of cardiomyopathy (approx. 60\% of patients diagnosed with cardiomyopathy) [9].

The treatment of cardiomyopathy is almost exclusively symptomatic. In the case of hypertrophic cardiomyopathy, alcohol septal ablation may be performed, which results in damage to a hypertrophied fragment of the interventricular septum, or septal myectomy, which contributes to reducing the stenosis of the left ventricular outflow tract. In patients with ARVC, if the application of antiarrhythmic drugs is ineffective, the arrhythmogenic regions may be ablated with radiofrequency current [9]. Conduction blocks, atrioventricular blocks in particular, are most common complications occurring after this surgery [10]. In this case, implantation of a pacemaker may be necessary. Some patients may be eligible for heart transplantation; however, it should be remembered that this procedure is very complicated, expensive, and few patients meet the criteria required for transplantation [11]. Therefore, the treatment of many patients in advanced stages of the disease is only symptomatic.

The primary goal of palliative care is to improve the quality of life of patients. The most common symptoms reported by patients with heart failure, hospitalised at the Department of Palliative Medicine, included: pain, dyspnoea, swelling as well as anxiety, sleep disorders and depression; therefore, treatment of these above-mentioned symptoms was necessary. The pain usually came from the musculoskeletal system; paracetamol was the most commonly applied analgesic drug, the patients were also administered opioid analgesics. It should be taken into consideration that some categories of drugs are not recommended in heart failure. Pain treatment with the use of non-steroidal and anti-inflammatory drugs is contraindicated, as it may exacerbate both symptoms and the underlying disease; therefore, the importance of non-pharmacological and local methods of pain treatment should be emphasised [12]. Opioid drugs administered intravenously also reduce the feeling of dyspnoea. Benzodiazepines are used to relieve the feeling of dyspnoea, especially in patients with exacerbated anxiety [13]. In order to normalise the intravascular volume status, the patients were administered diuretics. The majority of the treated patients $(60 \%)$ were administered antipsychotics in connection with their psychotic disorders that occurred i.a. due to chronic brain hypoxia.

There are no guidelines for specific pharmacological treatment of cardiomyopathy. Most often, causal treatment is not possible, and the treatment of all types of cardiomyopathy is mainly symptomatic, with the aim of normalising haemodynamic disorders. ACE inhibitors, beta-blockers and diuretics are commonly applied during the therapy [9]. A similar tendency was found among the patients subjected to this analysis. Drugs that cause the least possible side effects should be carefully selected in this group of patients and used in optimal doses.

In $42 \%$ of patients, a decrease in the intensity of symptoms was observed, which resulted in discharge of patients from the Palliative Medicine Department and referring them to further outpatient care. Unfortunately, the general condition of 9 patients (35\%), despite the treatment used, gradually deteriorated and the patients died. 
An increasing percentage of patients with heart failure have electronic devices implanted, the aim of which is to stop life-threatening arrhythmias. It should be remembered, however, that in patients with advanced heart failure, the device intervention does not save the patient from death but only modifies its mechanism [7]. High-voltage therapies are often associated with unpleasant feelings, significantly impair the quality of life and are perceived as persistent therapy. Patients and their guardians should be provided with comprehensive information regarding the field of operation of the devices as well as modification of ICD or CRT-D settings should be proposed early enough [14], which does not disable cardiac stimulation and does not directly contribute to the patient's death [15].

In addition to comprehensive treatment, the foundation of palliative care is also the acceptance of unfavourable prognosis, not only by patients, but also by the patients' relatives and the medical team taking care of the patients [16]. The acceptance of the approaching end of life makes it possible to focus on the primary goal of palliative care, i.e. reduction of suffering [17].

The care provided in inpatient hospices and palliative medicine units is intended for both patients with cancer and those with other progressive, incurable diseases [8]. In Poland, patients with diagnosed non-cancer diseases constitute only approx. $10 \%$ of patients provided with palliative care [18]. These patients include those diagnosed with respiratory failure, atrophic diseases of the nervous system, diseases caused by human immunodeficiency virus (HIV) and pressure ulcers. According to the Resolution of the Minister of Health, patients with circulatory failure may be provided with palliative care only if the cause of the disease is cardiomyopathy. In the case of other causes leading to heart failure, such as ischaemic heart disease, hypertension or valvular defects - that are much more common than cardiomyopathies - palliative care is not provided, which is a serious problem since many patients are not provided with palliative care. The limited access to palliative care services is affected by the lack of NHF (National Health Fund) funding beyond the limit set out in the contract [1].

Patients with diagnosed cardiomyopathy constitute a small group of patients receiving palliative care, due to their low frequency in the population, however, they should not be marginalised. Many physicians do not know exactly which disease entities are provided with guaranteed palliative care services. In many patients, the term 'hospice' evokes bad associations with suffering and dying, so it is important to have a holistic approach to patients and make sure they have access to pharmacological treatment, physiotherapy as well as spiritual care. It is essential to establish rules of conduct in advanced stages of diseases, with a preference for methods that are the least onerous for the patient. A decision should be made on the possible termination of high-voltage therapy and limitation of the number of drugs applied to the minimum extent necessary. [19] The course of heart failure is much less predictable than the progress of disseminated cancer disease. Close cooperation between palliative medicine specialists and cardiology specialists is necessary. Palliative care combined with causal treatment can significantly improve the patients' quality of life [20].

\section{Conclusions}

In Poland, cardiovascular diseases are the most common cause of death, whereas access to palliative care for this group of patients is limited and not fully guaranteed. The current list of disease entities guaranteed with medical treatment should be carefully considered and extended to include patients diagnosed with heart failure.

\section{Conflict of interests}

Authors declare no conflict of interest.

\section{Funding}

This study has no funding.

\section{References}

1. Najwyższa Izba Kontroli: Zdążyć z pomocą. https://wwww. nik.gov.pl/aktualnosci/opieka-paliatywna-i-hospicyjna.html (20 December 2019).

2. Kościuczuk U, Jakubów P, Siemiątkowski A, et al. Hospitalization of palliative non-cancer patients in a stationary hospice $-z$ observational center study in Białystok. Palliat Med Practices. 2018; 12(1): 1-7.

3. Instytut Kardiologii, Kardiomiopatie i zapalenie mięśnia sercowego. http://www.ikard.pl/kardiomiopatie-i-zapalenie-miesnia-sercowego.html (21 October 2019).

4. Rogers JG, Patel CB, Mentz RJ, et al. Palliative Care in Heart Failure: The PAL-HF Randomized, Controlled Clinical Trial. J Am Coll Cardiol. 2017; 70(3): 331-341, doi: 10.1016/j. jacc.2017.05.030, indexed in Pubmed: 28705314.

5. Mentz RJ, Tulsky JA, Granger BB, et al. The palliative care in heart failure trial: rationale and design. Am Heart J. 2014; 168(5): 645-651.e1, doi: 10.1016/j.ahj.2014.07.018, indexed in Pubmed: 25440791.

6. Antonione $\mathrm{R}$, et al. Palliative care in the cardiac setting: a consensus document of the Italian Society of Cardiology / Italian Society of Palliative Care (SIC/SICP). G Ital Cardiol (Rome). 2019; 20(1): 46-61.

7. Sobański P, Krajnik M. Opieka paliatywna nad osobami z niewydolnością serca. In: De Walden-Gałuszko K, Ciałkowska-Rysz A. ed. Medycyna Paliatywna. Wydawnictwo Lekarskie PZWL, Warsaw 2015: 320-332.

8. Journal of Laws of 2013, item 1347: Rozporządzenie Ministra Zdrowia z dnia 29 października 2013 r. w sprawie świadczeń gwarantowanych z zakresu opieki paliatywnej 
i hospicyjnej [Regulation of the Minister of Health of 29 October 2013 on guaranteed palliative and hospice services.

9. Budaj A. Choroby układu krążenia. In: Interna Szczeklika. Podręcznik chorób wewnętrznych. Medycyna Praktyczna Publishing House, Kraków 2019: 378-390.

10. Agarwal S, Tuzcu EM, Desai MY, et al. Updated meta-analysis of septal alcohol ablation versus myectomy for hypertrophic cardiomyopathy. J Am Coll Cardiol. 2010; 55(8): 823-834, doi: 10.1016/j.jacc.2009.09.047, indexed in Pubmed: 20170823.

11. Mandeep R, Mehra MD, Charles E, et al. The 2016 International Society for Heart Lung Transplantation listing criteria for heart transplantation: A 10-year update (Guidelines) . J Heart Lung Transplant. 2015; 35(1).

12. Sobański P, Grodzicki T, Krajnik M. Opieka Paliatywna nad chorymi z niewydolnością serca. Omówienie stanowiska ekspertów European Association for Palliative Care 2019. Medycyna Praktyczna Publishing House. 2019(10): 10-18.

13. Krajnik M. Duszność $i$ inne problemy kliniczne w opiece nad chorym w stanie terminalnym - co powinien wiedzieć internista. https://www.mp.pl/wyklady_wideo/interna/interna2014/102174, dusznosc-i-inne-problemy-kliniczne-w-opiece-nad-chorym-w-stanie-terminalnym-co-powinien-wiedziec-internista (30 January 2020).

14. Lewis KB, Stacey D, Matlock DD. Making decisions about implantable cardioverter-defibrillators from implantation to end of life: an integrative review of patients' perspec- tives. Patient. 2014; 7(3): 243-260, doi: 10.1007/s40271014-0055-2, indexed in Pubmed: 24668214.

15. Pasierski T. Zaburzenia ze strony układu krążenia. In: Ciałkowska-Rysz A, Dzierżanowski T. ed. Medycyna Paliatywna. Termedia Publishing House, Poznań 2019: 163-167.

16. Sobański P, Stec $S$, Opolski G. Niewydolność serca jako cel dla medycyny paliatywnej. Medycyna Paliatywna w Praktyce. 2010; 4(4): 168-172.

17. Lemond L, Allen LA. Palliative care and hospice in advanced heart failure. Prog Cardiovasc Dis. 2011; 54(2): 168-178, doi: 10.1016/j.pcad.2011.03.012, indexed in Pubmed: 21875515.

18. Zapewnienie opieki paliatywnej i hospicyjnej - Informacja o wynikach kontroli NIK. https://www.nik.gov. pl/plik/id,21371,vp,24011.pdf (30 January 2020).

19. Pasierski T. Modification of cardiovascular pharmacotherapy in palliative care patients with cancer: a narrative review. Pol Arch Intern Med. 2017; 127(10): 687-693, doi: 10.20452/pamw.4098, indexed in Pubmed: 28918428.

20. Jaarsma $T$, Beattie JM, Ryder M, et al. Advanced Heart Failure Study Group of the HFA of the ESC. Palliative care in heart failure: a position statement from the palliative care workshop of the Heart Failure Association of the European Society of Cardiology. Eur J Heart Fail. 2009; 11(5): 433-443, doi: 10.1093/eurjhf/hfp041, indexed in Pubmed: 19386813. 


\section{Analiza dokumentacji medycznej chorych z rozpoznaniem kardiomiopatii objętych stacjonarną opieką paliatywną}

Artykuł jest tłumaczeniem pracy: Niemiec A., Siejak W., Niemiec M., El-Zein R. An analysis of medical records of patients diagnosed with cardiomyopathy and provided with inpatient palliative care. Palliat. Med. Pract. 2020 tom 14, nr 1: 7-11. Należy cytować wersję pierwotną.

Piśmiennictwo znajduje się na stronach 10-11.

\section{Streszczenie}

Opieka paliatywna, obecnie nazywana również wspierającą, jest opieką specjalistyczną, która koncentruje się na poprawie jakości życia poprzez łagodzenie objawów i stresu u pacjentów z nieuleczalną chorobą. Podejmowane działania służą zapobieganiu cierpienia, leczeniu bólu i innych objawów somatycznych oraz pomocy w rozwiązywaniu problemów psychosocjalnych i duchowych wraz ze wsparciem dla rodziny pacjenta.

Niewydolność serca spowodowana kardiomiopatią należy do chorób nieuleczalnych, ograniczających funkcje życiowe, w których są udzielane świadczenia gwarantowane z zakresu opieki paliatywnej i hospicyjnej. Choroba ma charakter postępujący, a terapia spowalnia jedynie przebieg choroby, co oznacza, że rozpoznanie będzie towarzyszyć chorym przez całe życie, a u części będzie przyczyną śmierci.

W artykule dokonano analizy dokumentacji chorych z rozpoznaniem kardiomiopatii, u których standardowe metody leczenia, pozwalające na poprawę funkcji serca, okazały się nieskuteczne. W celu poprawy jakości życia pacjenci zostali przekazani na Oddział Medycyny Paliatywnej.

Palliat Med Pract 2020; 14, 1: 12-15

Słowa kluczowe: kardiomiopatia, leczenie, niewydolność serca, objawy

\section{Wstęp}

Większość pacjentów oddziałów medycyny paliatywnej w Polsce stanowią chorzy na nowotwory $(83,4 \%)$ [1], jednakże aktualne dane epidemiologiczne wskazują na wzrost zapotrzebowania na opiekę hospicyjną wśród pacjentów cierpiących na choroby nienowotworowe, w tym zaawansowaną niewydolność serca [2]. Niewydolność serca jest częstym schorzeniem, zwłaszcza wśród starzejącego się społeczeństwa i może mieć różne przyczyny. Jedną z grup chorób, które prowadzą do rozwoju niewydolności krążenia, stanowią kardiomiopatie.

Kardiomiopatie można podzielić na pierwotne i wtórne - wywołane toksycznym działaniem leków, na przykład chemioterapeutyków, ale także spowodowane przez choroby metaboliczne, endokrynologiczne czy autoimmunologiczne [3]. Opieka paliatywna u pacjentów z kardiomiopatią obejmuje leczenie objawów somatycznych (m.in. ból, duszność, nudności, obrzęki) i łagodzenie stresu psychicznego [4]. Postępujący charakter kardiomiopatii w połączeniu z wysoką śmiertelnością

\section{Adres do korespondencji:}

Aleksandra Niemiec

Ośrodek Medycyny Paliatywnej i Hospicyjnej Będkowo

e-mail: alex.niemiec@gmail.com 
powoduje, że opieka paliatywna stanowi istotny element postępowania terapeutycznego [5]. Standardowe leczenie nie zawsze pozwala wystarczająco zmniejszyć cierpienie pacjenta i znacząco poprawić jego jakość życia [6].

Należy podkreślić, że chorzy na kardiomiopatie, zwłaszcza w zaawansowanych stadiach choroby, cierpią na liczne choroby towarzyszące, często niedostatecznie rozpoznane i leczone. Nierzadko występują interakcje lekowe pomiędzy stosowanymi preparatami leczniczymi. Zakres opieki powinien być skoordynowany $z$ leczeniem podstawowym i obejmować leczenie objawów związanych z chorobą [7]. Zgodnie z załącznikiem do Rozporządzenia Ministra Zdrowia z dnia 29 października 2013 roku dotyczącego opieki paliatywnej, świadczeniami gwarantowanymi mogą być objęci chorzy z rozpoznaniem kardiomiopatii [8].

\section{Pacjenci i metody}

Przeanalizowano historie choroby 26 pacjentów z rozpoznaniem kardiomiopatii, objętych opieką w Ośrodku Medycyny Paliatywnej i Hospicyjnej w Będkowie. Analizowani pacjenci przebywali na Oddziale w okresie od 26 maja 2014 roku do 15 stycznia 2020 roku. Analizowano wiek, płeć, rodzaj kardiomiopatii, a także choroby wspótistniejące, stosowane leczenie farmakologiczne i niefarmakologiczne oraz obecność wszczepialnych urządzeń elektronicznych. Z powodu nieinterwencyjnego charakteru obserwacji, badanie zwolniono z wymogu zgody Komisji Bioetycznej.

\section{Wyniki}

W grupie 26 poddanych analizie chorych było 17 mężczyzn (65\%) i 9 kobiet (35\%), średnia wieku wynosiła 74 lata. Najstarszy pacjent miał 95 lat, a najmłodszy 36 lat. Najliczniejszą grupę stanowili pacjenci z kardiomiopatią niesklasyfikowaną - 13 osób, u 11 chorych rozpoznano kardiomiopatię rozstrzeniową, a u 2 pacjentów kardiomiopatię przerostową. Przyczyną skierowania wszystkich chorych na oddział medycyny paliatywnej było nasilenie objawów niewydolności krążenia spowodowanej chorobą podstawową. Z analizy chorób towarzyszących (tab. 1) wynika, że pacjenci z kardiomiopatią cierpią najczęściej na nadciśnienie tętnicze, a także cukrzycę, zaburzenia rytmu serca, choroby nerek i zaburzenia gospodarki lipidowej. U ponad połowy chorych $\mathrm{w}$ wywiadzie stwierdzono więcej niż dwie wymienione choroby.

Pacjenci na oddziału medycyny paliatywnej zostali skierowani z oddziałów internistycznych innych szpitali. Średni czas pobytu chorych na oddziale medycyny paliatywnej wynosił 79 dni (najkrótszy czas hospitalizacji -1 dzień, najdłuższy -497 dni);
Tabela 1. Choroby towarzyszące pacjentom z kardiomiopatią w opiece paliatywnej

\begin{tabular}{llcc}
\hline $\begin{array}{l}\text { Choroby } \\
\text { współwystępujące }\end{array}$ & Liczba & $\begin{array}{c}\text { Odsetek wy- } \\
\text { stępowania }\end{array}$ \\
\hline 1. & Nadciśnienie tętnicze & 18 & 69 \\
\hline 2. & Cukrzyca & 9 & 35 \\
\hline 3. Zaburzenia rytmu serca & 10 & 38 \\
\hline 4. Zawał serca & 12 & 46 \\
\hline 5. & Udar mózgu & 9 & 35 \\
\hline 6. & Choroby nerek & 6 & 23 \\
\hline
\end{tabular}

9 chorych zmarło, 15 wypisano z Oddziału, 4 pacjentów przekazano na oddział chorób wewnętrznych, a 11 pacjentów skierowano do Hospicjum Domowego lub POZ. Ponadto, 2 chorych w ostatnim dniu analizy nadal przebywało na oddziale medycyny paliatywnej.

W leczeniu stosowano najczęściej beta-adrenolityki i leki przeciwzakrzepowe lub przeciwpłytkowe, które podawano 21 chorym (81\%) (ryc. 1). Leki działające na ośrodkowy układ nerwowy (przeciwlękowe, przeciwpsychotyczne, nasenne, przeciwdepresyjne) stosowano u 18 pacjentów (69\%), diuretyki pętlowe lub tiazydowe stosowano u 17 pacjentów, opioidowe leki przeciwbólowe u 15 chorych. Oprócz wymienionych farmaceutyków, pacjenci otrzymywali leki przeciwcukrzycowe, inhibitory konwertazy angiotensyny, sartany i leki hipolipemizujące. $\mathrm{U}$ większości chorych stosowano tlenoterapię bierną donosowo lub przez maskę twarzową. U wszystkich chorych kontrolowano diurezę, prowadzono dobowy bilans płynów i raz na dobę mierzono obwód brzucha celem wykluczenia przewodnienia. Ponadto, 5 pacjentów miało wszczepione urządzenia elektroniczne wspomagające prawidłową czynność serca: 3 chorych stymulator VVI, pozostali - układ resynchronizujący CRT-D lub ICD. Wszystkich chorych poddano ostrożnej, indywidualnie dobranej fizjoterapii i otrzymali wsparcie psychologiczne udzielane im wraz z ich bliskimi.

\section{Dyskusja}

Świadczenia gwarantowane z zakresu opieki paliatywnej i hospicyjnej mogą zostać udzielone pacjentom, u których rozpoznano jednostki chorobowe wymienione w Rozporządzeniu Ministra Zdrowia z 29 października 2013 roku [8]. Lista dotycząca pacjentów dorosłych jest ograniczona; ze schorzeń kardiologicznych obejmuje jedynie kardiomiopatie. Nie wszyscy lekarze specjaliści kardiologii i chorób wewnętrznych są poinformowani o tym fakcie i w związku z tym, pomimo wskazań, nie kierują pacjentów do jednostek opieki paliatywnej. Aby zapewnić chorym z kardiomiopatią jak najlepszą jakość opieki, niezwy- 


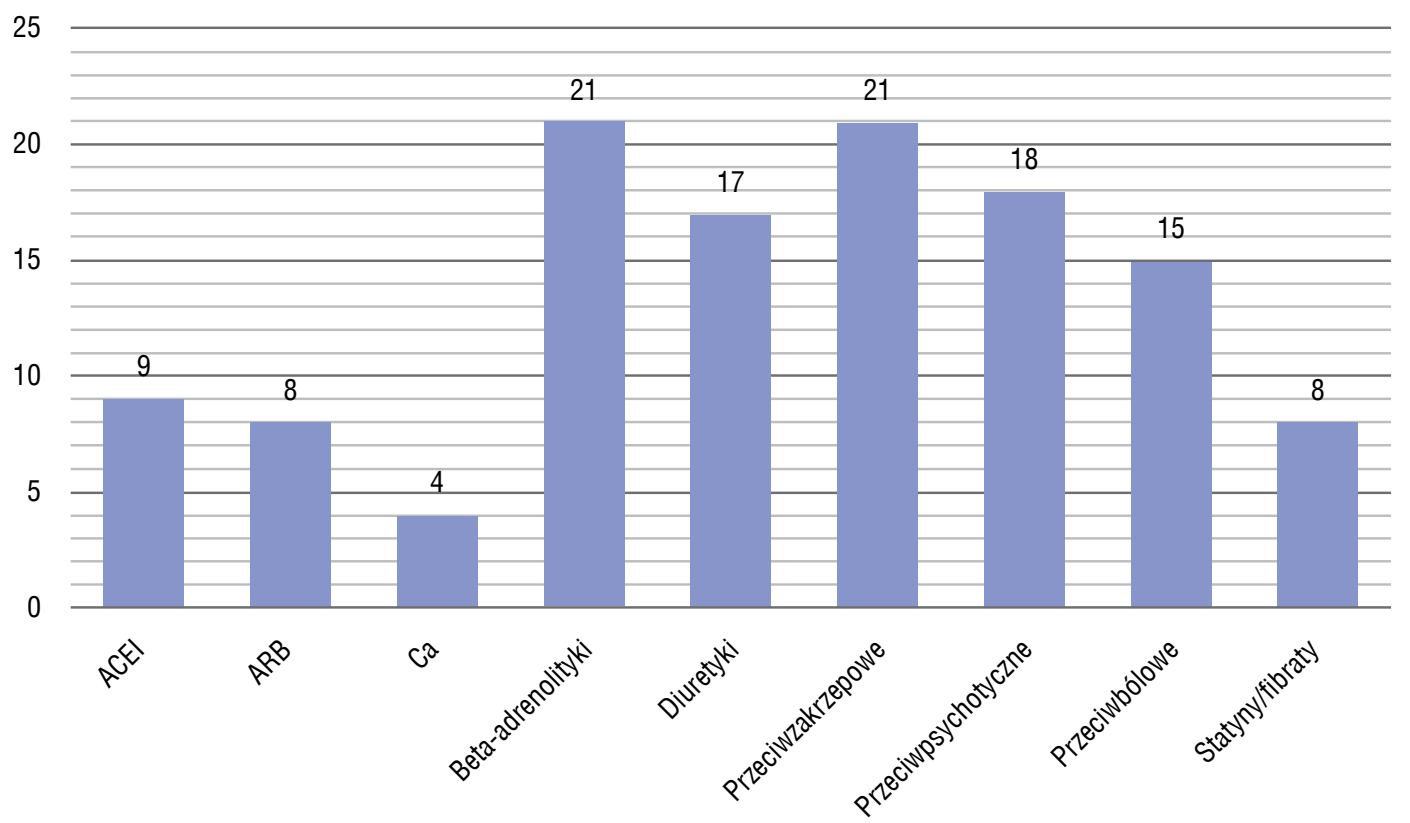

Rycina 1. Leki stosowane przez pacjentów z kardiomiopatią w opiece paliatywnej. ACEI — inhibitory konwertazy angiotensyny; ARB — antagonista receptora angiotensyny II; Ca — blokery kanałów wapniowych

kle istotne jest podjęcie jak najwcześniej współpracy specjalisty kardiologa i medycyny paliatywnej.

Kardiomiopatie prowadzą do dysfunkcji serca, a w konsekwencji do jego niewydolności, a ich etiologia jest zróżnicowana. Zgodnie z podziałem Światowej Organizacji Zdrowia (WHO, World Health Organization) wyróżniono kardiomiopatię roztrzeniową, przerostową, restrykcyjną, arytmogenną kardiomiopatię prawokomorową i kardiomiopatie niesklasyfikowane. Według danych pochodzących z podręcznika „Interna Szczeklika 2020", najczęściej występuje kardiomiopatia rozstrzeniowa (u ok. $60 \%$ chorych z rozpoznaniem kardiomiopatii) [9].

Leczenie kardiomiopatii jest niemal wyłącznie objawowe. W przypadku kardiomiopatii przerostowej można wykonać ablację alkoholową, w efekcie czego dochodzi do uszkodzenia przerośniętego fragmentu przegrody międzykomorowej, lub miektomię przegrody międzykomorowej, co przyczynia się do zmniejszenia zwężenia drogi odpływu krwi z lewej komory serca. $\mathrm{U}$ chorych z arytmogenną kardiomiopatią prawokomorową, jeżeli stosowanie leków antyarytmicznych jest nieskuteczne, można przeprowadzić ablację miejsc arytmogennych prądem o częstotliwości radiowej [9]. Spośród powikłań, dość często po przeprowadzeniu zabiegu występują bloki przewodzenia, głównie bloki przedsionkowo-komorowe [10]. Konieczne może okazać się wówczas wszczepienie stymulatora. Część pacjentów może zostać zakwalifikowana do zabiegu transplantacji serca, jednak należy pamiętać, że jest to procedura bardzo skomplikowana, kosztowna, a także nieliczni chorzy spełniają kryteria wymagane do kwalifikacji do przeszczepu [11]. W związku z powyższym u wielu pacjentów w zaawansowanym okresie choroby stosuje się jedynie leczenie objawowe.

Nadrzędny cel opieki paliatywnej stanowi poprawa jakości życia chorych. Do najczęstszych objawów, które zgłaszali pacjenci z niewydolnością serca hospitalizowani na oddziale medycyny paliatywnej, należały: ból, duszność, obrzęki, a także lęk, zaburzenia snu i depresja, niezbędne było zatem leczenie wymienionych objawów. Ból pochodził najczęściej z układu mięśniowo-szkieletowego, najczęściej stosowanym lekiem przeciwbólowym był paracetamol, chorzy otrzymywali również opioidowe leki przeciwbólowe. Należy wziąć pod uwagę fakt, że niektóre grupy leków nie są zalecane w niewydolności serca. Leczenie bólu przy użyciu niesteroidowych leków przeciwzapalnych jest przeciwwskazane, ponieważ może sprzyjać nasileniu objawów i powodować zaostrzenie choroby podstawowej, dlatego należy podkreślić znaczenie metod niefarmakologicznych i miejscowych leczenia bólu [12]. Leki opioidowe podawane drogą dożylną powodują również zmniejszenie uczucia duszności. Benzodiazepiny są stosowane wspomagająco $w$ łagodzeniu uczucia duszności, zwłaszcza u chorych z nasilonym lękiem [13]. Celem znormalizowania wolemii pacjentom zlecono diuretyki. Leki przeciwpsychotyczne w związku z zaburzeniami psychotycznymi, które występowały między innymi na skutek przewlekłego niedotlenienia mózgu otrzymywało $60 \%$ leczonych pacjentów. 
Brak wytycznych dotyczących swoistego leczenia farmakologicznego kardiomiopatii. Najczęściej leczenie przyczynowe nie jest możliwe, a leczenie wszystkich rodzajów kardiomiopatii jest głównie objawowe, przy czym celem jest normalizacja zaburzeń hemodynamicznych. W terapii powszechnie stosowane są inhibitory konwertazy angiotensyny, beta-adrenolityki i leki moczopędne [9]. Podobną tendencję stwierdzono wśród chorych poddanych w prezentowanej analizie. Należy starannie wybierać leki w tej grupie chorych, które powodują możliwie najmniej działań niepożądanych, a także stosować je w optymalnych dawkach.

U 42\% pacjentów zaobserwowano zmniejszenie natężenia objawów, co skutkowało wypisaniem chorych z oddziału medycyny paliatywnej i przekazaniem do dalszej opieki ambulatoryjnej. Niestety, stan ogólny 9 chorych (35\%), pomimo stosowanego leczenia, ulegał stopniowemu pogorszeniu i pacjenci zmarli.

$\mathrm{U}$ coraz większego odsetka chorych na niewydolność serca wszczepiane są urządzenia elektroniczne, które mają na celu przerwanie zagrażających życiu arytmii. Należy jednak pamiętać, że u chorych z zaawansowaną niewydolnością serca, interwencja urządzenia nie ratuje pacjenta przed śmiercią, a jedynie modyfikuje jej mechanizm [7]. Terapie wysokonapięciowe wiążą się często z przykrymi odczuciami, znacząco pogarszają jakość życia, a także są postrzegane jako uporczywa terapia. Należy udzielić chorym i ich opiekunom wyczerpujących informacji dotyczących zakresu działania urządzeń, a także zaproponować odpowiednio wcześnie modyfikację ustawień ICD, bądź CRT-D [14], co nie powoduje wyłączenia aktywności kardiostymulacyjnej i nie przyczynia się bezpośrednio do zgonu pacjenta [15].

Fundamentem opieki paliatywnej, oprócz kompleksowego leczenia, jest również akceptacja niepomyślnego rokowania, nie tylko przez chorych, ale również bliskich pacjenta i zespół opiekujący się chorym [16]. Akceptacja zbliżającego się końca życia pozwala na skupieniu się na podstawowym celu opieki paliatywnej, czyli zmniejszeniu cierpienia [17].

Opieka realizowana w hospicjach stacjonarnych i na oddziałach medycyny paliatywnej przeznaczona jest zarówno dla chorych na nowotwory, jak i inne postępujące, nieuleczalne choroby [8]. W Polsce pacjenci z rozpoznaniem chorób nienowotworowych stanowią jedynie około $10 \%$ chorych objętych opieką paliatywną [18]. Wśród tych pacjentów znajdują się chorzy z rozpoznaniem niewydolności oddechowej, chorób zanikowych układu nerwowego, chorób wywołanych przez ludzki wirus upośledzenia odporności i owrzodzeń odleżynowych. Pacjenci z niewydolnością krążenia, zgodnie z rozporządzeniem ministra zdrowia, mogą zostać objęci opieką paliatywną jedynie wówczas, kiedy przyczyną schorzenia jest kardiomiopatia. W przypadku innych przyczyn prowadzących do niewydolności serca, takich jak choroba niedokrwienna serca, nadciśnienie tętnicze czy wady zastawkowe, które występują znacznie częściej niż kardiomiopatie, świadczenia z zakresu opieki paliatywnej nie są dostępne, co stanowi poważny problem, ponieważ wielu chorych nie jest obejmowanych opieką paliatywną. $\mathrm{Na}$ ograniczony dostęp do świadczeń w zakresie opieki paliatywnej wpływa brak finansowania przez NFZ ponad limit określony w kontrakcie [1].

Pacjenci z rozpoznaniem kardiomiopatii stanowią nieliczną grupę chorych objętych opieką paliatywną, ze względu na niezbyt częste występowanie w populacji, jednak nie powinni być marginalizowani. Wielu lekarzy nie zna dokładnie jednostek chorobowych objętych świadczeniami gwarantowanymi z zakresu opieki paliatywnej. U wielu chorych nazwa hospicjum wywołuje złe skojarzenia związane z cierpieniem i umieraniem, dlatego istotne jest holistyczne podejście do pacjentów i zapewnienie leczenia farmakologicznego, fizjoterapii i opieki duchowej. Niezmiernie istotne jest ustalenie zasad postępowania w zaawansowanych okresie chorób z preferencją metod, które są najmniej uciążliwe dla pacjenta. Należy podjąć decyzję dotyczącą ewentualnej dezaktywacji terapii wysokonapięciowej, a także ograniczać liczbę stosowanych leków do jedynie niezbędnych [19]. Przebieg niewydolności serca jest znacznie mniej przewidywalny niż postęp rozsianej choroby nowotworowej. Niezbędna jest ścisła współpraca lekarzy specjalistów medycyny paliatywnej i kardiologii. Opieka paliatywna w połączeniu z leczeniem przyczynowym może znacząco poprawić jakość życia chorych [20].

\section{Wnioski}

W Polsce choroby układu krążenia stanowią najczęstszą przyczynę zgonów, natomiast dostęp do opieki paliatywnej tej grupy pacjentów jest ograniczony i nie w pełni zagwarantowany. Należałoby dogłębnie przemyśleć obecny wykaz jednostek chorobowych objętych świadczeniami gwarantowanymi i rozszerzyć o chorych z rozpoznaniem niewydolności serca.

\section{Konflikt interesów}

Autorzy deklarują brak konfliktu interesów.

\section{Finansowanie}

Badanie nie było finsowane. 